\title{
Liquidity Issues in the Banking Sector from an Accounting Perspective
}

\author{
Rosa Vinciguerra ${ }^{1}$, Nadia Cipullo ${ }^{2}$ \\ ${ }^{1}$ Department of Economics, University of Campania Luigi Vanvitelli, Capua, Italy \\ ${ }^{2}$ Link Campus University, Roma, Italy \\ Correspondence: Rosa Vinciguerra, Department of Economics, University of Campania Luigi Vanvitelli, Corso \\ Gran Priorato di Malta I, Capua, Italy.
}

Although the work is the result of the shared thoughts of the authors, paragraphs 1, 2, 3.1, 3.2, 3.3 and 4 are attributable to R. Vinciguerra and the paragraph 3.4 is attributable to N. Cipullo.

The authors are grateful for the valuable comments of the two anonymous referees.

\begin{tabular}{|c|c|c|}
\hline Received: February 23, 2018 & Accepted: April 4, 2018 & Online Published: April 23, 2018 \\
\hline doi:10.5539/ibr.v11n5p80 & URL: https://doi.org/10 & :v11n5p80 \\
\hline
\end{tabular}

\begin{abstract}
The recent financial crisis highlighted the inability of financial markets of being always able to cope with the liquidity needs of banks. This gave rise to a great attention to the issues related to the liquidity in the banking sector.

Stakeholders interested in assessing the liquidity profile of a financial institution can rely on data provided through its financial statements. This demonstrates the strong influence that the accounting discipline can have on it. Accounting standards can play an important role in depicting the liquidity profile (and the associated risk) of an entity, as they contribute to produce information useful to predict timing, uncertainties and amounts of its future cash flows.

The objective of this theoretical study has been to investigate the contents of the IASB Conceptual Framework and of some of its standards, i.e. IAS 7, IFRS 7, IFRS 9. In particular, the aim of the analysis has been to verify if the financial information requested by the regulation is adequately useful and relevant in order to assess the liquidity profile of a financial institution. In our opinion, the IASB discipline still presents some deficiencies on this aspect, in particular for entities operating in the banking sector.
\end{abstract}

Keywords: bank, business model, cash flows, disclosure, liquidity, financial instruments, measurement

\section{JEL: M40, M41}

\section{Introduction}

Before the recent financial crisis, market players used to neglect the importance of the risks connected to the liquidity. Indeed, it was customary to think that liquidity needs could be easily addressed by recurring to well-developed capital markets. Consistently, even regulators for the banking sector did not provide a common framework concerning the liquidity and the liquidity risk. The latter was not even taken into consideration as an autonomous risk in the Basel II Framework (BCBS, 2004).

In spite of that, the recent crisis revealed the deficiencies of that approach and the effects that a liquidity shortage could produce on single financial institutions as well as on the whole economy. These effects were even greater for the banking sector, whose prevailing activity still consists in collecting and deploying funds. Banks traditionally collect resources through deposits or bond issues. They use these capitals to provide funds to customers or to invest in securities portfolios with the dual purpose of generating financial revenues and to establish cash reserves, according to the deposit-funded model. Alternatively, banks can get cash resources through the process of securitization of receivables. This can be done by recurring to special purpose vehicles, according to the market-funded model (Mottura \& Paci, 2009). Additionally, the evolution of the banking business, from an Originate To Hold (OTH) to an Originate To Distribute (OTD) model $\left({ }^{\mathrm{i}}\right)$, made the business of a bank even more complex.

As a consequence, market players started seriously worrying about issues related to the liquidity. Indeed, it was 
revalued as being essential for preserving the stability of the entire financial system as well as the reliability of single institutions. For entities, for example, the greater is the liquidity, the greater is the possibility to adapt to unexpected needs and opportunities becomes. A condition of illiquidity, on the contrary, prevents the possibility to regularly carry out any activity.

These circumstances highlighted the need for a regulation. Unfortunately, however, the liquidity is not an easy notion to define and, hence, to regulate. First of all, a distinction has to be introduced between the endogenous and the exogenous liquidity concepts (Banks, 2014). The Endogenous Liquidity refers to the aspects specific of an institution and mainly within its direct control. A company can reasonably manage its endogenous liquidity by analysing its liquidity profile and assuming appropriate choices regarding the structure of assets' portfolios and securing liabilities. This concept of liquidity affects both the management and the financial reporting perspectives of a bank. The liquidity profile of a company changes every day and, as a consequence, managers need information in order to appreciate, to monitor and to deal with it (management perspective). On the other side, stakeholders and regulators are interested in the liquidity profile of the banks. Both of them can collect information about it through the financial statements (financial reporting perspective). The Exogenous Liquidity, instead, refers to the variables that are not under the direct control of any single institution. Nevertheless, sometimes, the actions of single individuals can contribute to influence it.

This paper focuses on the concept of endogenous liquidity of a bank, from the financial reporting perspective. The basic idea is that the information disclosed through the financial statements should be adequate to allow its readers to comprehend the liquidity profile of an entity. According to it, the study intends to analyse some of the current accounting regulation affecting the liquidity, in order to verify if the financial information requested are adequately useful and relevant for this purpose.

The focus of this study is directed to the current accounting regulation. However, the assessment of the liquidity may clearly be affected by many other factors (i.e. earnings management, conservatism, smoothing, etc.), that we plan to address in future works.

It is also obvious that all the activities of a bank can influence its liquidity; nevertheless, it still largely depends on its core business, which is mainly connected to financial instruments. Therefore, the research is restricted only to some accounting standards, in particular:

- $\quad$ IASB Conceptual Framework;

- $\quad$ IAS 7 - Statement of Cash Flows;

- $\quad$ IFRS 9 - Financial Instruments;

- $\quad$ IFRS 7 - Financial Instruments: Disclosure.

The rest of the paper is organised as follows. Section 2 analyses the concepts of liquidity, pointing out the differences between its main components; it describes the liquidity risk and outlines connections with accounting. Section 3 addresses issues related to the accounting discipline, underlining some critical points. Section 4 synthesizes the reached conclusions.

\section{Liquidity, Risk and Accounting}

\subsection{Liquidity}

Due to its importance in our study, it is useful to start clarifying the concept of liquidity. This section contains an overview of the different meanings associable to the liquidity concept. It also sheds light on the risks associated to the liquidity and on its links with the accounting regulation.

Liquidity (ii) is not an easy notion to define and does not have a univocal meaning. Even focusing the attention only on the endogenous liquidity, it can be seen at least from two points of view, the static and the dynamic one. From the static point of view, it can be intended as a stock. It coincides with cash and cash-equivalents available at a given time as the result of past events. It can be investigated through the construction of a cash flows statement that allows the understanding of how corporate transactions produced or absorbed it. However, the liquidity can also be seen from a dynamic perspective. Differently from the previous one, this interpretation does not take into account just the cash and the cash-equivalents available at a given time, but it considers the company's ability to fund its growth or to meet its obligations as they come due without incurring unacceptable losses (Banks, 2014; Duttweiler, 2009). The focus is shifted from a stock to a dynamic dimension (iii). In this way, the concept of liquidity should not be intended as a synonym of available cash and cash equivalents; it embraces a broader meaning. Not surprisingly, over time there have been different ways of understanding the liquidity depending, in turn, on why liquidity was required $\left({ }^{\mathrm{iv}}\right)$. For instance, we can refer to the following theories from 
the recent literature:

a) Adam Smith saw as basic source of bank liquidity short-term loans advanced to finance salable goods on the way from producer to consumer (Real Bills Theory of Liquidity);

b) Moulton saw the liquidity in the ability to sell or shift loans from one to another bank than in the repayment of the loans themselves (Shiftability Theory of Liquidity);

c) Prochnow looked again at loans - rather at investments - as source of liquidity. However, according to his approach, the liquidation of a loan was not connected to the sale of the assets, nor to the the shift of the terms of the loan, but to the anticipated income of the borrower (The Anticipated Income Doctrine of Liquidity);

d) during the 60 's, banks started to raise cash through access to new or additional funds. The Liability Management View of Liquidity (or Illiquidity) was the tool through which the bank collected the funds and managed the balance sheet growth;

e) in the last few years, banks started to simultaneously manage the asset and the liability sides of their balance sheets, according to the basic premise of matching the quantities of their asset and liability portfolios from a liquidity point of view (The Balance Sheet Management View of Liquidity).

Ultimately, therefore, from a dynamic point of view the liquidity can be defined as the company's ability to fund its growth or to meet its obligations as they come due, without incurring unacceptable losses.

Accordingly, in order to understand the liquidity profile of a company does not seem sufficient to put attention only on its cash and/or cash equivalents, as well as on words from its cash flows statements: they capture only an historical accounting perspective, while is needed a prospective one too. Moreover, this information is partial; actually the liquidity reflects several components that must be investigated. These elements are the Funding Liquidity, that refers to liabilities from which the cash can be drawn; the Asset Liquidity that relates to the availability of assets which can be sold or pledged in order to obtain cash; the Liquidity Contingencies, connected to forthcoming events, that can impact on future cash flows (Banks, 2014).

\subsection{Liquidity and Risk}

Each entity, carrying out its own business, faces many types of risks (Knight F.H., 1921). A rough distinction can be made between operational risks, consisting in losses affecting the operating activity, and financial risks. The Market Risk is a kind of financial risk involving losses in on and off-balance sheet positions due to adverse movements in market prices. The Credit Risk, that is another financial risk, refers to losses due to uncertainty in a counterparty's ability to meet its financial obligations. The Liquidity Risk is a financial risk too. It refers to losses arising from a lack of cash or of its equivalents, as well as from the inability to obtain it (through funding at an economically reasonable levels or through selling/pledging assets at their carrying prices), in order to meet both expected and unexpected obligations (Banks, 2014) $\left({ }^{v}\right)$. The liquidity is inversely related to the risk for the entity of becoming illiquid (Nikolaou, 2009).

In theory, if a firm could own assets and liabilities well matched (in terms of their duration) and if it could keep them until their maturity, assuming the absence of new transactions, then it should not face the liquidity risk. With these conditions, indeed, maturing assets will provide funds needed to repay liabilities as they come due. Such a model, however, is not truthful; it is static and ideal. It could be true neglecting the maturity transformation, that characterizes the function of intermediation of the banks and of the financial institutions; and ignoring the contingencies and their impacts on future scenarios. Accordingly, all entities, especially the financial ones, must consider and manage the liquidity risk. The comprehension of the liquidity risk requires the assessment of its components, which are (Banks, 2014): the Asset Liquidity Risk, due to the inability to convert assets into cash at the expected value ( $\left.{ }^{\mathrm{vi}}\right)$; the Funding Liquidity Risk, arising from an inability to access unsecured funding sources at an economically reasonable cost in order to meet obligations ( $\left.{ }^{\mathrm{vii}}\right)$; the Joint Asset/Funding Liquidity Risk, that occurs when the Asset and the Funding Liquidity Risks jointly happen. It gives rise to systemic liquidity risk, consisting in the drainage of liquidity circulating in the whole financial system; the Liquidity Mismatches Risk, that happens when maturities of assets and liabilities do not match, leading to divergent cash inflows and outflows over time and to the consequential losses; the Liquidity Contingencies Risk, that refers to losses resulting from unexpected future events absorbing liquidity flows.

\subsection{Liquidity and Accounting}

The liquidity profile of a company and the connected risks cannot be disjointed from the accounting regulation. Since the information useful to be acquainted with an entity are produced according to accounting rules and are 
widespread through the financial reporting, the above mentioned components of the liquidity and of the liquidity risk could be influenced by the accounting discipline.

The values ascribed to the recognized assets should be predictive of the amount of cash flows that will be potentially produced by the company at the moment when these assets will be realized. In addition, the provided disclosure should offer the information useful in order to understand, if not clear, the times in which these assets will be realized. Therefore, it is reasonable to expect that the asset liquidity risk might be influenced by accounting regulations. In this case, particular attention should be given to the policies concerning the measurement and the disclosure regarding the assets. In particular, in the asset measurement, accounting standards should be able to assign appropriate carrying values, as they are the starting point to identify future cash flows.

The accounting discipline could potentially influence the liability side too. In this case, its impact may vary depending on the aspect upon which emphasis is given. When the focus is on the funding liquidity, interpreted as the bank inability to settle obligations with immediacy, it is important to know the amount of cash needed to cope with the liability and the moments in which the money has to be available. From the accounting point of view, policies concerning the measurement and the disclosure become important. If reference is made to the funding liquidity risk, that is the inability to access unsecured funding sources at economically reasonable costs in order to meet obligations, accounting rules do not play a direct role. In this case, the bank's ability to obtain new funds rather depends on its reputation, which could be reflected in its rating profile. However, if the bank adopts a market-funded model, with financial resources obtained through the securitization of receivables rather than through the deposits or bonds (deposit-funded model), reference should be made to the asset liquidity risk.

During the last years, banks started to manage concurrently assets and liabilities, matching their quantities from a liquidity standpoint, according to the Business Model pattern (Cinquini \& Tenucci, 2011; EFRAG 2013a). In these circumstances, it is important to know the cash flows that will be absorbed or produced from investments managed simultaneously, with details of their times of occurrence, otherwise the company could run into a situation of liquidity mismatches risk. As a consequence, accounting standards should be consistent with a portfolio strategy. Banks transfer funds from savers to borrowers; because of the gap between lending agreements and often shorter liabilities, the loan activity may expose the bank to the liquidity mismatch risk. In order to mitigate it, the bank can maintain some of its assets as a cash reserve and/or invest a portion of its available funds in financial instruments, other than in loans and/or prefer more liquid instruments as investments. Banks take these decisions adopting a portfolio approach: they disregard single investments and consider jointly assets and liabilities, consistent with the management strategy. Since these decisions respond to different business models, criteria for classification and measurement of involved financial instruments should be consistent with this rationale. Otherwise, the focus on single financial assets or liabilities may lead to an improper classification/measurement of items in the statement of financial position and provide a misleading liquidity representation of the entity.

The accounting discipline should also require to provide information about the liquidity contingencies risk. In this case, the risk is linked to losses caused by unlikely future events. The accounting discipline cannot request the recognition of elements within the financial statements, rather, it should require to produce disclosure about the awareness of the risk of unlikely future events that could absorb cash flows in the future.

Furthermore, financial analysts usually adopt ratios and margins in order to assess the liquidity profile of a company. In the accounting literature, for example, liquidity is often calculated in terms of net liquid assets, expression of a firm's financial position (Pizzo, 2010; Pizzo, Moscariello \& Vinciguerra, 2015). Other traditional measures used in practice are: a) the Liquidity Gap, defined as the difference between volatile liabilities and liquid assets (Culp, 2001); b) the Funding Ratio, useful to observe the structural Liquidity Risk in a bank's balance sheet. It is calculated as the sum of available funding above $n$ years divided by the sum of assets maturing above the same period, (Matz \& Neu, 2007); c) Ratios referring to cash inflows and outflows for a defined period, usually a short one (Matz \& Neu, 2007; Duttweiler, 2009); d) the Liquidity stress testing and scenario analysis, that is a recent metric considering if the entity is able to meet its obligations over a short time period in a severe stress scenario. Even the Basel Committee (BCBS, 2013; BCBS 2010) introduced the Liquidity Coverage Ratio (LCR), in order to evaluate the short-term resilience of a bank's Liquidity Risk, and the Net Stable Funding Ratio (NSFR), to promote resilience over a longer time horizon.

These references show that the comprehension of the liquidity profile of a financial institution is built on data provided through the financial statements. This highlights the strong influence that the accounting discipline can have on it. 


\section{Weaknesses of the IASB Discipline from the Liquidity Perspective}

In accordance with the previous contents, it is reasonable to assume that the accounting rules may exert an influence on the financial information regarding the liquidity profile of a financial institution. In this section, an investigation on the contents of the conceptual framework and of certain accounting standards will help us to understand if they require information that are adequate in order to make financial statements useful and relevant in assessing the liquidity profile of a bank.

The analysis will concern only some accounting principles. It is undeniable that the liquidity profile of a bank is affected by many accounting standards. However, the impossibility to analyse all of them drove the choice to focus only on those that have been deemed more influent for the banking sector. Therefore, the attention will be focused on the IASB Conceptual Framework for Financial Reporting (IASB, 1989; IASB, 2010); the IAS 7 Statement of Cash Flows (IASB, 2007a); the IFRS 9 - Financial Instruments (IASB, 2014); the IFRS 7 Financial Instruments: Disclosure (IASB, 2007b).

\subsection{The Conceptual Framework for Financial Reporting}

The IASB Conceptual Framework for Financial Reporting (CFFR) states that the objective of general purpose financial reporting (GPFR) is to provide financial information to existing and potential investors, lenders and other creditors useful to make decisions about providing resources to the entity. As accounting data represent the basis for taking economic decisions, they should be relevant and give a faithful representation, providing correct signals to their users. The CFFR asserts that these stakeholders need information useful to help them in assessing the prospects for future net cash inflows to an entity. So, they "need information about the resources of the entity [and] claims against the entity" (IASB, 1989; IASB, 2010), useful to predict future cash flows, to assess liquidity and the ability to obtain financing (IASB, 2010).

Although one of the objective of the Conceptual Framework is to provide information regarding the future net cash inflows to an entity, useful to assess its liquidity, the IASB does not clarify what is the meaning of liquidity (viii). The Conceptual Framework should delineate the concept of liquidity and of its various components, since this might be useful as guidance in the interpretation of financial information.

Also the concept of Business Model is not sufficiently clarified in the Conceptual Framework (not even in the Exposure Draft - Conceptual Framework for Financial Reporting (IASB, 2015). Entities, especially ones operating in the banking sector, in the management of their financial assets and liabilities take on a business model based on the portfolio approach. The adopted business model influences the evaluation criteria to be implemented and, therefore, the information provided. It should be noted however that the Exposure Draft Conceptual Framework for Financial Reporting introduces the concept of Unit of Account. That is "the group of rights, the group of obligations or the group of rights and obligations, to which recognition and measurement requirements are applied." (IASB, 2015). The objective of the Unit of Account is to provide useful information to stakeholders about the entity's future cash flows.

Although the introduction of the concept of Unit of Account improved the contents of the Conceptual Framework, the inclusion of both the liquidity and the business model concepts could help to make its contents more complete and make it a better guide for the preparation and understanding of the GPFR.

\subsection{IAS 7 - Statement of Cash Flows}

The objective of the IAS 7 - Statement of Cash Flows is to require information about the historical changes in cash and cash equivalents of an entity through a statement, which classifies the cash flows in operating, investing and financing activities (IASB, 2007a). The IASB states that, thanks to this information, users of financial statements should be able to assess the liquidity of the entity, its ability to generate cash and cash equivalents, its necessities to use those cash flows. Moreover, historical cash flows information could be used as an indicator of the amount, timing and certainty of future cash flows (IASB, 2007a) ${ }^{\mathrm{ix}}$ ).

First of all, it is necessary to point out that the notion of cash equivalents could be different for companies operating in the banking sector. According to IAS 7 definitions, "cash equivalents are short-term, highly liquid investments that are readily convertible to known amounts of cash and which are subject to an insignificant risk of changes in value" (IASB, 2007a). Differently, banks, in identifying the assets that can be treated as cash, may focus their attention on HQLA - High Quality Liquid Asset; between them, they can even consider "long-term government securities available as a collateral for refinancing transactions with a central bank" (EFRAG, 2015a).

Concerning the liquidity, intended as the company's ability to fund its growth or to meet its obligations as they come due without incurring unacceptable losses, it depends (mostly) on assets and liabilities existing at the 
reporting date. As a consequence, the statement of cash flows, made at the end of the reporting period, cannot provide sufficient information useful to assess the liquidity profile of an entity; it can just provide indirect information on it, showing past changes in cash and cash equivalents and their reasons. However, even this indirect information could be incomplete from a liquidity perspective; we are thinking, for example, about changes due to non-cash movements (i.e. fair value changes; foreign exchange rate changes; commencement of a leases (EFRAG, 2015a)) and for which is not requested a reconciliation statement (i.e. especially for financial assets and financial liabilities). Moreover, as financial assets and financial liabilities are held according to a portfolio view, information provided with reference to individual classes of assets and liabilities could be meaningless.

In addition of being indirect and incomplete, the information can be misleading too. In the banking sector, the adopted distinction between operating, investing and financing activities is meaningless and could conduct to provide distorted information. Such as, for example, when "the purchase of some financial assets (are) presented as investing outflows, but if these investments are transferred to a different category, their ultimate sale or redemption is presented as an operating cash flow" (EFRAG, 2015a). This aspect may lead to doubting the relevance of information provided.

Finally, the IAS 7 could be completed with the explicit analysis of the meaning of liquidity; moreover the difference between the concept of liquidity and the notion of cash flow should be clarified. The standard could also be improved through the introduction of a different point of view, reflecting characteristics of companies operating in the banking sector. Financial institutions usually operate according to a different concept of cash equivalents and a distinctive meaning of operating activities. These actions could make historical information about changes in cash and in cash equivalents more relevant and faithful.

\subsection{IFRS 9 - Financial Instruments}

Assets and liabilities of financial institutions consist almost exclusively of financial instruments. Subsequently, the IFRS 9 is one of the main documents to be investigated, even if it does not explicitly refer to banks. After a brief description of its contents, in this paragraph we illustrate its weaknesses in providing sufficient useful and relevant information concerning the liquidity.

The IFRS 9 has the objective of establishing "principles for the financial reporting of financial assets and financial liabilities that will present relevant and useful information to users of financial statements for their assessment of the amounts, timing and uncertainty of an entity's future cash flows" (IASB, 2014). To this end, it identifies different methods of measurement, depending on the adopted Business Model. In particular, financial assets can be measured at Amortized Cost (AC), at Fair Value Through Other Comprehensive Income (FV-OCI), or at Fair Value Through Profit and Loss (FV-PL) according to both the entity's business model for managing the financial assets and their contractual cash flow characteristics (IASB, 2014); financial liabilities are measured at Amortized Cost, unless some exceptions (IASB, 2014).

A financial asset shall be measured at $\mathrm{AC}$ when it is held within a business model whose objective is to collect contractual cash flows and the contractual terms give rise, on specified dates, to cash flows that are solely payments of principal and interest on the principal outstanding (IASB, 2014). This method of measurement is suitable to provide useful information to predict future cash flows for financial instruments held to maturity, considered that value fluctuations occurring before their expiry do not impact their cash flows. On the other hand, financial asset owned for trading shall be measured at FV-PL. In this case, the fair value, as an exit price (IASB, 2011), better reflects potential cash flows connected to financial instruments owned for trading. Besides these two extreme situations (financial instruments held to maturity and those held for trading), an entity can own financial instruments that, although held in order to collect contractual cash flows, can be sold if occur some requirements connected to the Business Model. For example, financial assets hold in order to collect contractual cash flows could be sold: a) if there is an increase in the asset's credit risk and they do not longer meet the credit criteria documented in the entity's investment policy (IASB, 2014); b) to manage credit concentration risk (IASB, 2014). In these circumstances, the IFRS 9 states that financial assets shall be measured at FV-OCI overcoming the limit of the previous version of the IFRS 9 (Vinciguerra \& Cipullo, 2014a; 2014b). An entity may also use the Fair Value Option (at initial recognition, instead of FV-PL, if it eliminates, or significantly reduces a measurement or recognition inconsistency) or measure equity instruments at FV-OCI.

In general, the criteria suggested from the standard for measuring financial instruments provides carrying values useful in order to identify future cash flows.

However, it should be noted a concern about the hybrid contracts. According to IFRS 9, if a hybrid contract contains a financial asset, an entity shall measure the entire hybrid contract according to measurement methods 
as previously described. The standard does not allow the "bifurcation" between the embedded derivative and the host instrument. So that, carrying values (of the host and of the embedded parts) should be able to express future cash flows associated with the specific underlying financial instrument. However, if the bifurcation is not granted, the embedded value will be linked to the measurement criteria of the host part and, in some cases, the prediction of cash flows associated with the financial instrument in its entirety could be undermined. As in the case of a financial asset with an equity conversion option: it "would not have contractual cash flows that are solely principal and interest and would be measured at FV-PL because the return on the instrument would not only reflect the time value of money and the credit risk of the instrument; rather, the return would be linked to the value of equity" (EFRAG, 2013b); or when the host is hold for trading and the entire hybrid contract has to be measured at Fair Value, even if the embedded component returns reflect just the time value of the money and the credit risk. On the other side, IFRS 9 allows the "bifurcation" for financial liabilities. This approach introduces differences in the treatment of financial assets and financial liabilities and is not consistent with the bank's business model, where assets and liabilities are considered under a portfolio perspective. The decision of the IASB increases complexity and risk of not complying with the business model's rationale and introduces asymmetry in accounting for financial assets and financial liabilities (EFRAG, 2015b). From the liquidity point of view, it can also alter the usefulness of the information provided.

From a further analysis, were also evident the following frailties: a) the standard, in defining the interest rate, refers to the liquidity risk (IASB, 2014), as a component of the risk premium, (EFRAG, 2013b; EBA, 2013a) but does not clearly specify to which notion of liquidity it is referring to; b) despite the crisis of 2008, the standard does not take into account the the notion of illiquidity of financial instruments, whereas it might be advisable do not measure the illiquid instruments at Fair Value (European Association Co-operative Banks, 2013); c) the possibility afforded by the standard of choosing different options, leaves room for accounting choices (EBA, 2012).

Moreover, information required by the standards in certain cases could suffer from some limitations. Between them, for instance, there are:

- differences between the carrying value and the associated liquidity potential (namely, the liquidity obtained in the event or realization);

- disparities between timing and economic maturity of certain items;

- occurrence of unrecognized and unrecognizable items (for example, the bank's rating profile and its reputation, although not recognizable, can influence its ability to access funding, as well as the bargaining power in trading; moreover, there are future events that may affect cash flows while non presenting conditions for recognisability).

These gaps should be filled by disclosure, whose analysis is the object of the next section.

\subsection{IFRS 7 - Financial Instruments: Disclosure}

For readers' convenience, here the main aspects regarding the IFRS 7 have been summarized following a previous work (Vinciguerra \& Cipullo 2014c), to which refer for a deeper analysis.

The IFRS 7 requires entities to provide narrative disclosure to integrate and improve the information value of quantitative data. Entities are expected to offer information that enables users to evaluate the impact of financial instruments on their performance and financial position; the nature and extent of risks arising from financial instruments to which the entity is exposed and how the entity manages those risks (IASB, 2007b).

The main issues associated to the IFRS 7 contents and related to the liquidity and to the liquidity risk relates to three main aspects.

The first one deals with "What" should be disclosed and concerns values, maturities and timing of cash flows.

As carrying values could diverge from the financial instrument's liquidity potential, in order to complete the information already required by IFRS 7, entities could present a table of reconciliation and explain the causes for differences. Entities could also provide information on the amount and the composition of liquidity reserves and on stocks of assets available for liquidity purposes, free of regulatory, legal or contractual charges and that could be used as collateral or pledged to secure liabilities (i.e. unencumbered assets); summarise encumbered and unencumbered assets in a tabular format by balance sheet categories, including collateral received that can be re-hypothecated or otherwise redeployed (FSB, 2012). Unfortunately, is still missing a clear and internationally accepted definition of asset encumbrance (EBA, 2013b; EBA, 2013c). Indeed, IFRS 7 requires to disclose only fair values of collaterals and financial assets pledged to secure liabilities (BCBS, 2013), but does not give many 
references to the amount of liquidity reserves detained for liquidity management, except for deposits at Central Banks (IASB, 2007b), as well as criteria used to identify the so called High Quality Liquid Assets (IASB, 2007b). Disclosure should be given about contractual and/or expected maturities of on and off-balance sheet items and timing of cash inflows and outflows, divided in time buckets or bands, built using different assumptions (normal and stressed period - scenario analysis). The reference to contingencies, commitments and unrecognized items, such as intangibles, could be useful in order to properly depict the liquidity situation of the bank. For each bucket, the difference between assets giving origin to cash inflows and liabilities giving origin to cash outflows, would provide the "Cumulative Funding Gap", useful to assess maturity mismatches for each period of time. For demand or non-maturity deposits, loans with pre-payment options and structured notes, cash flows could be ascertained using the bank's maturity estimates for certain balance sheet items; additional disclosure should explain assumptions used in the assessment of behavioural liquidity characteristics when these materially differ from the contractual maturity (FSB, 2012; FSB, 2013). Concerning this point, IFRS 7 states that an entity shall disclose a maturity analysis assessing an appropriate number of time bands; in determining cash flows and bands banks must refer on contractual maturities, with no reference at expected or behavioural liquidity characteristics or off-balance sheet items. In case of demand deposits and for all items to which are connected a range of possible maturities, cash flows are included on the basis of the earliest date on which the entity can be required or is permitted to pay (IASB, 2007b). Entities are also asked to disclose how hedging activities may affect the amount, timing and uncertainty of its future cash flows (IASB, 2007b). Definitively, the standard appears quite poor relative to these issues, as it does not consider timing and economic maturity (quite typical for banks) of certain liabilities and cash flows associated to unrecognized items.

The second aspect relates on "How" previously identified information should be disclosed. On this aspect, more than required by IFRS 7 (a split between qualitative and quantitative information and a representation of significant concentrations of liquidity risk, in asset/funding liquidity), an addition of tables and their explanations could be a useful complement; a disaggregation of information about values and maturities according to different currencies, geographical areas, markets, counterparties and business lines, could enable a better assessment of the concentration of the liquidity risk in each identified segment (CFA, 2013). The overall quality of disclosure could be improved by providing definition of key terms, inputs and assumptions for indicators used to assess liquidity and funding positions; narrative commentary on contractual maturity; analysis of financial assets and liabilities other than figures and connections with the entity's strategy and objectives in terms of funding and liquidity (ESMA, 2013). A better portrait of liquidity also requires more information as (EFRAG, 2008): a) whether assets can be easily sold or refinanced in order to raise funds (asset liquidity); b) the stability and diversification of sources of funding, including regular and potential sources resulting from the occasional sale or refinancing of assets (funding liquidity); c) stress analysis, including testing whether the liquidity buffers would be sufficient to face the occurrence of a stress scenario (liquidity contingencies).

Finally, it is important to determine "When" information should be disclosed. As liquidity is not a static concept, (ECB, 2006), disclosure provided in financial statements may not be enough for investors to ascertain the liquidity risk of a bank, making appropriate to periodically integrate it by the use of some other documents, such as risk reports $\left({ }^{\mathrm{x}}\right)$, operating and financial reviews, management commentaries $\left.{ }^{\mathrm{xi}}\right)$.

In summary, more disclosure, than those already requested, are needed in order to provide information useful to assess the liquidity profile of financial assets and liabilities.

\section{Conclusions}

The objective of this theoretical study has been the investigation of the contents of some accounting standards in order to verify if their requirements are adequate to ensure useful and relevant financial statements to assess liquidity profiles in the banking sector.

To this end, it was first analysed the concept of liquidity, underlying the difference with the notion of cash. For the purposes of this survey, the liquidity was defined as the company's ability to fund its growth or to meet its obligations as they come due, without incurring unacceptable losses. Then, connections between the liquidity and the business risks were presented, highlighting the peculiarities of the liquidity risk. The influence of the accounting discipline on the information regarding the liquidity was also pointed out, emphasizing its importance in the process of evaluation of the financial position of an entity.

Subsequently, the contents of the IASB Conceptual Framework and of the accounting standards considered most relevant in the banking industry (IAS 7; IFRS 9; IFRS 7) have been analysed.

Despite its intention to provide information regarding the future net cash inflows to an entity, useful to assess its liquidity, the Conceptual Framework lacks to define or to sufficiently clarify the concept of liquidity. It is also 
missing the concept of Business Model, notwithstanding the importance it plays within the context of companies operating in the banking sector.

The IAS 7 - Statement of Cash Flows ignores to consider the differences between the liquidity and the cash flows. It provides information, that could be used in order to predict future cash flows, that are indirect and incomplete. This information could be also misunderstood because of the distinctive meaning of the operating activities in the banking sector.

The IFRS 9 - Financial Instruments, in its improved version (compared to that of 2010), besides a problem concerning the treatment of the hybrid contracts, still does not fully explain the meaning of liquidity, does not take into account the notion of illiquidity and leaves room for accounting choices.

The IFRS 7 - Financial Instruments: Disclosure still miss to require some of the information that could be needed to assess the liquidity profile of financial assets and liabilities.

\section{References}

AAA - American Academy of Actuaries (2000). "Report of the American Academy of Actuaries Life of Liquidity Working Group" (Washington, DC).

https://www.actuary.org/files/publications/Interim\%20Report\%20on\%20stress\%20liquidity\%2009-01-2000 .pdf

Aureli, S., \& Salvatori, F. (2013). Investigation of Risk Management and Risk Disclosure Practices of Italian Listed Local Utilities, Financial Reporting, 1, 121-167. https://doi.org/10.3280/FR2013-001006

Banks, E. (2014). Liquidity Risk - Managing Funding and Asset Risk - Second Edition. (Palgrave Macmillan Global Financial Markets)

BCBS - Basel Committee on Banking Supervision (2004). International Convergence of Capital Measurement and Capital Standards. A Revised Framework. https://www.bis.org/publ/bcbs107.htm

BCBS - Basel Committee on Banking Supervision (2010). Basel III: International Framework for Liquidity Risk and Measurement, Standards and Monitoring. https://www.bis.org/publ/bcbs188.pdf

BCBS - Basel Committee on Banking Supervision (2013). Basel III: The Liquidity Coverage Ratio and Liquidity Risk Monitoring Tools. https://www.bis.org/publ/bcbs238.htm

BIS - Basel Committee on Banking Supervision (2008). Principles for Sound Liquidity Risk Management. https://www.bis.org/publ/bcbs144.htm

Buzzichelli, F., \& Di Pietra, R. (2013). Risk Profile Disclosure Requirements for Italian Insurance Companies: Differences in the Financial Statement Preparation, Financial Reporting, 1, 43-79. https://doi.org/10.3280/FR2013-001004

CFA Institute - Chartered Financial Analyst (2013). Financial Reporting Disclosures. Investor Perspectives on Transparency, Trust and Volume. https://www.cfapubs.org/doi/pdf/10.2469/ccb.v2013.n12.1

CIA - Canadian Institute of Actuaries (1996). Liquidity Risk Measurement. http://www.actuaries.ca/members/publications/1996/9626e.pdf

Cinquini, L., \& Tenucci, A. (2011). Business Model in Management Commentary and the Links with Management Accounting, Financial Reporting, 3-supp., 41-59.

Cole, C. J. (2012). “Corporate Liquidity Disclosures: A Review”,.The Journal of Corporate Accounting \& Finance, 65-77. https://doi.org/10.1002/jcaf.21814

CSBS - Conference of State Bank Supervisors (2010). Interagency Policy Statement of Funding and Liquidity Risk Management. https://www.fdic.gov/news/news/financial/2010/fil10013.html

Culp, C. L. (2001). The Risk Management Process - Business Strategy and Tactics. (Wiley).

Drehman, M., \& Nikolau, K. (2010). Funding Liquidity Risk: Definition and Measurement, BIS - Bank for International Settlements Working Papers No 316. https://www.bis.org/publ/work316.htm

Duttweiler, R. (2009). Managing Liquidity in Banks - A Top Down Approach. (Wiley)

EBA - European Banking Authority (2012). "New Bank Liquidity Rules: Dangers Ahead”, A Position Paper by EBA's Banking Stakeholder Group. https://www.eba.europa.eu/documents/10180/807776/20121002_BSG_Liquidity_Paper_incl_amendment.p df 
EBA - European Banking Authority (2013a). Comment Letter to Exposure Draft Classification and Measurement: Limited Amendments to IFRS 9.

EBA - European Banking Authority (2013b). Consultation Paper: Draft Implementing Technical Standards on Asset Encumbrance Reporting Under Article 95a of the Draft Capital Requirements Regulation.

EBA - European Banking Authority (2013c). Report on Appropriate Uniform Definitions of Extremely High Quality Liquid Assets (Extremely HQLA) and High Quality Liquid Assets (HQLA) and on Operational Requirements for Liquid Assets Under Article 509(3) and (5) CRR. https://www.eba.europa.eu/documents/10180/16145/EBA+BS+2013+413+Report+on+definition+of+HQL A.pdf

$E C B$ - European Central Bank (2006). Assessment of Accounting Standards from a Financial Stability Perspective.

https://www.ecb.europa.eu/pub/pdf/other/assessmentaccountingstandards2006en.pdf?a1415598edf0845669 bc3b33248da0d3

EFRAG - European Financial Advisory Group (2013a). The Role of the Business Model in Financial Statements, Research Paper.

https://www.efrag.org/Assets/Download?assetUrl=\%2Fsites\%2Fwebpublishing\%2FSiteAssets\%2FBusiness $\% 2520$ Model\%2520Research\%2520Paper.pdf

EFRAG - European Financial Reporting Advisory Group (2008). Comment Letter on IASB Exposure Draft: Improving Disclosures About Financial Instruments.

EFRAG - European Financial Reporting Advisory Group (2013b). Draft Comment Letter to the IASB Exposure Draft Classification and Measurement: Limited Amendments to IFRS 9.

EFRAG - European Financial Reporting Advisory Group (2015a). EFRAG Short Discussion Series - THE STATEMENT OF CASH FLOWS ISSUES FOR FINANCIAL INSTITUTIONS. https://www.efrag.org/Activities/335/Statement-of-Cash-Flows-issues-for-Financial-Institutions

EFRAG - European Financial Reporting Advisory Group (2015b). Endorsement Advice on IFRS 9 Financial Instruments.

https://www.efrag.org/Assets/Download?assetUrl=\%2Fsites\%2Fwebpublishing\%2FSiteAssets\%2FEndorse ment\%2520Advice\%2520on\%2520IFRS\%25209.pdf

ESMA - European Securities and Markets Authorities (2013). Review of Accounting Practices. Comparability of IFRS Financial Statements of Financial Institutions in Europe. https://www.esma.europa.eu/document/review-accounting-practices-comparability-ifrs-financial-statements -financial-institutions

European Association Co-operative Banks (2013). Comment Letter to Exposure Draft Classification and Measurement: Limited Amendments to IFRS 9.

FSB - Financial Stability Board (2012). Enhancing the Risk Disclosures of Banks Report of the Enhanced Disclosure Task Force (EDTF).

FSB - Financial Stability Board (2013). Progress Report of the Enhanced Disclosure Task Force (EDTF). http://www.fsb.org/wp-content/uploads/r_130821a.pdf

IASB - International Accounting Standards Board (1989). Framework for the Preparation and Presentation of Financial Statements.

IASB - International Accounting Standards Board (2007a). IAS 7 - Statement of Cash Flows.

IASB - International Accounting Standards Board (2007b). IFRS 7: Financial Instruments: Disclosure.

IASB - International Accounting Standards Board (2011). IFRS 13 Fair Value Measurement.

IASB - International Accounting Standards Board (2014). IFRS 9: Financial Instruments.

IASB - International Accounting Standards Board (2015). ED/2015/3 Exposure Draft on Conceptual Framework for Financial Reporting.

IASB- International Accounting Standard Board (2010). Conceptual Framework for Financial Reporting.

Knight, F. H. (1921). Uncertainty and Profit. (The London School of Economics and Political Science). https://mises.org/sites/default/files/Risk,\%20Uncertainty,\%20and\%20Profit_4.pdf 
Lawson, G. H. (1971). Cash Flow Accounting. Accountant, 386-389.

Lawson, G. H. (1978). The Rationale of Cash Flow Accounting, in Cees Van Dam (ed.), Trends in Managerial and Financial Accounting, pp. 85-104, (Leiden, The Netherlands: Martinus Nijhoff Social Sciences Division). https://doi.org/10.1007/978-1-4613-4062-1_5

Lawson, G. H. (1985). The Measurement of Corporate Performance on a Cash Flow Basis: a Reply to Mr. Egginton, Accounting and Business Research, 99-108. https://doi.org/10.1080/00014788.1985.9729253

Lee, T. A. (1972). A Case for Cash Flow Reporting. Journal of Business Finance, 27-36.

Lee, T. A. (1981). Reporting Cash Flows and Net Realisable Values, Accounting and Business Research, 163-170. https://doi.org/10.1080/00014788.1981.9729693

Matz L.M. and Neu P. (2007). Liquidity Risk Measurement and Management. A Practitioner's Guide to Global Best Practices. (John Wiley \& Sons (Asia) Pte Ltd).

Matz, L. M.-a (2011). Liquidity Risk Measurement and Management - Basel III and Beyond, (Xlibris).

Matz, L. M.-b (2011). Liquidity Risk Management. (Sheshunoff \& Co).

Mottura, P., \& Paci, S. (a cura di) (2009). Banca - Economia e gestione, Milano Egea.

Nikolaou, K. (2009). Liquidity (Risk) Concept - Definitions and Interactions, ECB - European Central Bank Working paper Series, No 1009.

http://www.ecb.europa.eu/pub/pdf/scpwps/ecbwp1008.pdf?56d2038eb68e90a4fd0bfa9098f5b272

Office of the Superintendent of Financial Institutions (Canada) (2012). Liquidity Principles. http://www.osfi-bsif.gc.ca/Eng/fi-if/rg-ro/gdn-ort/gl-ld/Pages/b6.aspx

Pizzo, M. (2010). La Posizione Finanziaria Netta nella Dottrina e nella Prassi Contabile: brevi note, in (a cura di Airoldi G., Brunetti G., Corbetta G., Invernizzi G.) Scritti in onore di Vittorio Coda, Milano, Egea.

Pizzo, M., Moscariello, N., \& Vinciguerra, R. (2015). Market Incentives and Regulators' Activity Shaping Financial Information: An Analysis of the Net Debt Disclosure in Italy. International Journal of Business and Management, 10(1), 1-13. http://www.ccsenet.org/journal/index.php/ijbm/article/view/42077/23810

Staubus, G. J. (1989). Cash Flow Accounting and Liquidity: Cash Flow Potential and Wealth, Accounting and Business Research, 19(74), 161-169. https://doi.org/10.1080/00014788.1989.9728846

Vinciguerra, R., \& Cipullo, N. (2014a). Basel III VS Accounting Standards in the Liquidity Reporting. Universal Journal of Accounting and Finance 2(2), 47-51. http://www.hrpub.org/download/20140525/UJAF3-12290058.pdf

Vinciguerra, R., \& Cipullo, N. (2014b). The impact of IFRS 9 and IFRS 7 on Liquidity in Banks: Theoretical

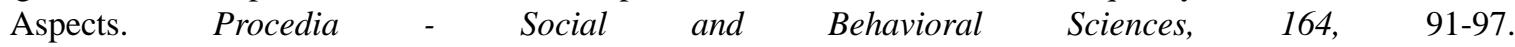
https://doi.org/10.1016/j.sbspro.2014.11.055

Vinciguerra, R., \& Cipullo, N. (2014c). Missing Requirements On Disclosure Discipline Concerning Liquidity, Conference Proceedings - The International Conference on Accounting \& Finance, May 2014. https://tiikm.com/publication/ICAF-2014-online-proceedings-book.pdf

\section{Notes}

i In the Originate to Hold Model (OTH) a lender makes a loan with the intention of holding it through maturity, as opposed to selling it to other financial institutions and/or investors, as in the case of the Originate To Distribute Model (OTD).

ii Liquidity and Solvency have different meanings. The latter is "the condition of having sufficient funds to cover losses. [...] is a function of capital adequacy." (Matz, 2011a). However, they are somehow connected: "A positive status of solvency is a precondition for being liquid. As liquidity, in contrast to solvency, is solely cash related, it is possible to be solvent and illiquid at the same time" (Duttweiler, 2009).

iii For other references regarding the definition of liquidity see: CSBS - Conference of State Bank Supervisors, Interagency Policy Statement of Funding and Liquidity Risk Management, 2010; AAA - American Academy of Actuaries, "Report of the American Academy of Actuaries Life of Liquidity Working Group", Washington, DC, 2000; BIS - Basel Committee on Banking Supervision, Principles for Sound Liquidity Risk Management, 2008; 
Office of the Superintendent of Financial Institutions (Canada), Liquidity Principles, 2012.

iv "Just as current thinking on why we need liquidity has gone through an evolutionary process that has, in major respects, returned to old and sometimes abandoned ideas, concepts about liquidity sources have also evolved and returned, in part, to previously disregarded concepts." Matz, Leonard M., Liquidity Risk Management, 2011a, Appendix A, Xlibris.

v Other definitions are available in Duttweiler R., Managing Liquidity in Banks - A top down approach, Wiley, 2009, p. 10; in CIA - Canadian Institute of Actuaries, Liquidity Risk Measurement, March 1996, p. 4; in Culp C.L., The Risk Management Process - Business Strategy and Tactics, Wiley, 2001, chapter 17.

vi It can also depend on "the possibility that the financial institution could lose access to one or more markets because of concerns about the following: its own creditworthiness; the creditworthiness of a major counterparty; generally stressful market conditions." (Matz, 2011b).

vii See also Drehman and Nikolau, Funding Liquidity Risk: Definition and Measurement, BIS - Bank for International Settlements, Working Papers No 316, 2010.

viii The concept is missing also in the Discussion Paper DP/2013/1 - A Review of the Conceptual Framework for Financial Reporting as well as in the Exposure Draft ED/2015/3 Conceptual Framework for Financial Reporting

ix According Lawson and Lee ex post and ex ante cash flow reporting is useful in order to assess firm liquidity. See: Lawson G.H., Cash Flow Accounting, Accountant, October 18, 1971, pp.386-389; Lawson G.H., The Rationale of Cash Flow Accounting, in Cees Van Dam (ed.), Trends in Managerial and Financial Accounting, Leiden, The Netherlands: Martinus Nijhoff Social Sciences Division, 1978, pp. 85-104; Lawson G.H., The Measurement of Corporate Performance on a Cash Flow Basis: a Reply to Mr. Egginton, Accounting and Business Research, Spring 1985, pp.99-108; Lee T.A., A Case for Cash Flow Reporting, Journal of Business Finance, Summer 1972, pp.27-36; Lee T.A., Reporting Cash Flows and Net Realisable Values, Accounting and Business Research, Spring 1981, pp.163-170). Staubus asserts that cash flow potential incorporates the amount, timing, risk and cost of capital features that determine the market value of a prospective cash flow stream. See: Staubus G.J., Cash Flow Accounting and Liquidity: Cash Flow Potential and Wealth, Accounting and Business Research, Vol. 19, No. 74, 1989, pp. 161-169. According to the CFA Institute the Direct Method (to prepare the Cash Flow Statement) "better equips investors with the information necessary to appraise a company's liquidity, assess its earnings quality, and make more realistic cash flow forecasts". CFA Institute, Financial Reporting Disclosures. Investor Perspectives on Transparency, Trust and Volume, July 2013, p. 92

$x$ For an analysis of the risk disclosure practices in other sectors, see: Aureli S., Salvatori F., Investigation of Risk Management and Risk Disclosure Practices of Italian Listed Local Utilities, Financial Reporting, 2013(1); Buzzichelli F., Di Pietra R., Risk Profile Disclosure Requirements for Italian Insurance Companies: Differences in the Financial Statement Preparation, Financial Reporting, 2013(1).

xi For an example related to liquidity disclosures in the MD\&A see: Cole C. J., Corporate Liquidity Disclosures: A Review, The Journal of Corporate Accounting \& Finance, November/December 2012, pp. 65-77.

\section{Copyrights}

Copyright for this article is retained by the author(s), with first publication rights granted to the journal.

This is an open-access article distributed under the terms and conditions of the Creative Commons Attribution license (http://creativecommons.org/licenses/by/4.0/). 